K05200

\title{
ターボ機械内部流の非定常性について (現象理解と空力·伝熱設計への展開)
}

\section{Unsteady Flow Phenomena in Turbomachinery (What we know about them and how to use them in aero-thermal design of turbomachinery) ○正 船㟝 健一 ${ }^{* 1}$}

Ken-ichi FUNAZAKI ${ }^{* 1}$,

*1 岩手大学 Iwate University

Key Words : Turbomachinery, Unsteady Flow, Hi-Fi CFD, Experiment, POD, Deterministic Stress

\section{概 要}

ターボ機械は流体と羽根車との間での連続的なエネルギー変換を行う機械であり、製造、発電、輸送、交通、 給排水、空調、医療、など、人間のほとんど全ての活動を支える極めて重要な流体機械である。

流体現象そのものは本質的に非定常的であり、その非定常性がターボ機械のエネルギー変換機能や機械的特性 （振動、強度）面に何らかの影響は与えているとは考えられるものの、適切な平均操作を行うとともに検査空間 の取り方を工夫することで、定常流として角運動量の定理を適用することが可能となり、その結果としてエネル ギー交換を定量的に予測することができる（例えばオイラーの理論揚程の式）。そして、その予測值（理論值）を 基準としてエネルギー変換の効率を定義することができる。そのようなスタンスでターボ機械の空力設計手法は 整備されている。もちろん、流れの非定常性や流れによって引き起こされる非定常現象はターボ機械の研究者や 開発者、ユーザに強く認識されており、非定常現象に関する研究例は枚挙の睱のないが、設計フローにおいては 定常流（時間平均流）を仮定して通路形状、翼形状が設計されており、現時点においても非定常性を考慮した空 力設計法（ガスタービンの場合は伝熱設計法も含め）は確立されているとは言いがたい。

本講演では、岩手大学で行われている研究成果（Fig.1、Fig.2）を中心として、ターボ機械内部流の非定常性に ついての理解やそれらの知見がどの程度空力・伝熱設計一反映されているかについて概説するとともに、今後の 研究の展開について私見を述べる。ただし、筆者の研究テーマが主としてタービンに偏っており、本講演の内容 にもそれが反映されていることをご容赦頂きたい。

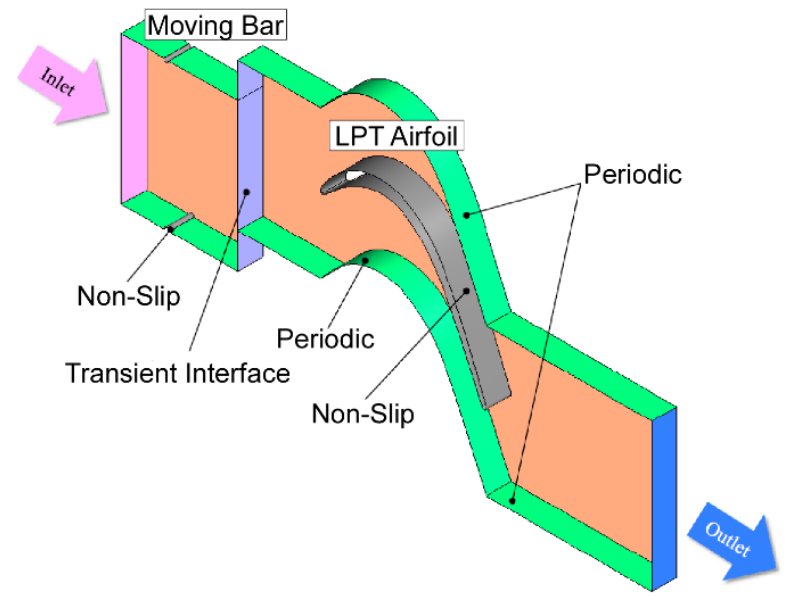

Fig. 1 Computational domains and boundary conditions

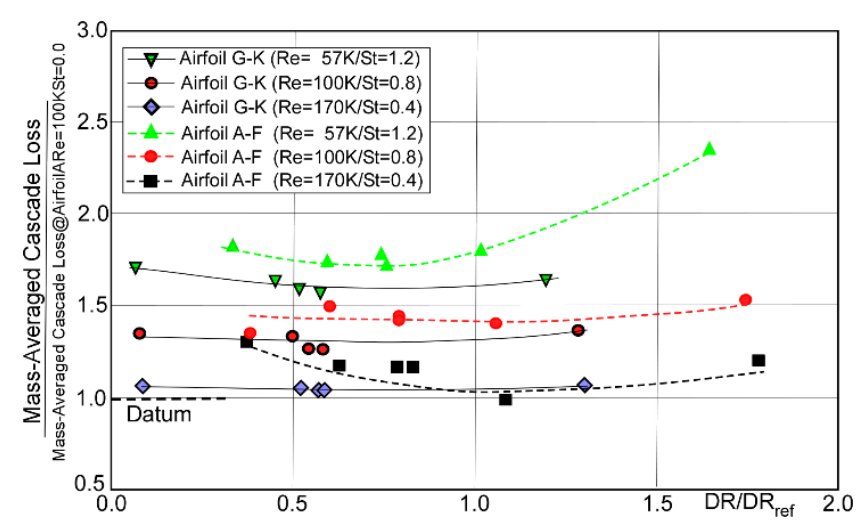

Fig. 2 Dimensionless cascade loss with incoming wake 